\title{
POLA PENCEMARAN BAKTERI FECAL COLIFORM PADA TANAH RESAPAN SEPTIC TANK LIMBAH CAIR RUMAH SAKIT
}

\author{
Asri D. Utami*, Anita Dewi $\mathbf{M}^{*}$, Cahyoadi Bowo** \\ *Fakultas Kesehatan Masyarakat Universitas Jember \\ **Lembaga Penelitian Universitas Jember
}

\begin{abstract}
The drain field distance of wastewater's septic tank to digging well plays important role in sanitation. It contributes to movement of fecal coliform through soil which follows the water flow. The objective of the research was to study the movement of fecal coliform in the soil. One water sample and 5 soil samples were collected from 0 to $2 \mathrm{~m}$ soil depth. Laboratory analysis has been done to quantify the fecal coliform bacteria. Spatial distribution of fecal coliform bacteria is analyzed using Surfer program. Pore size distribution and hydraulic conductivity analyzed with empirical method based on particle size laboratory analyzed. Our results indicated the digging well's water and soil sample from the drain field were contaminated with fecal coliform bacteria. The laboratory results showed digging well's water was contaminated with $>2400$ MPN/100 ml of fecal coliform. Meanwhile, soil sample were contaminated with 7 to 1600 MPN fecal coliform in different depth. Analysis on soil samples showed pore size distribution was dominated by mesopore and moderate hydraulic conductivity. Unperfect digging well construction as well as the high rate of hydraulic conductivity were determined as driving factors on fecal coliform movement. The empirical model offecal coliform movement give information about estimating period of the contaminated wells water.
\end{abstract}

Key words: Fecal coliform, pore size distribution, hydraulic conductivity

1) Corresponding Address : Asridyah.SKM@gmail.com

\section{PENDAHULUAN}

Pengelolaan limbah cair rumah sakit di Indonesia berdasarkan data tahun 2004 (Wisaksono, 2001), sebagian besar masih menggunakan septic tank. Sebanyak 372 rumah sakit masih menggunakan septic tank untuk pengelolaan limbah cairnya, terdiri dari 205 rumah sakit swasta (70\%), 125 rumah sakit Pemerintah 
(52\%), dan 42 rumah sakit TNI/ POLRI (84\%). Teknologi pengolahan limbah cair rumah sakit dengan menggunakan septic tank berpotensi besar menimbulkan masalah, apabila sistemnya tidak baik. Resapan air limbah dari septic tank bisa mengandung bakteri coli, yang dikhawatirkan dapat mencemari tanah dan sumber air. Terkait dengan pencemaran tersebut, faktor jakak terhadap sumber air (sumur), memegang peranan yang penting karena berpengaruh terhadap kecepatan resapan air limbah dari septic tank. Kecepatan resapan air limbah dari septic tank dipengaruhi oleh bebe-rapa faktor seperti faktor hidrogeologi (distribusi pori dan konduktivitas hidraulik tanah) dan faktor curah hujan. Faktor-faktor tersebut akan mempengaruhi pola gerakan bakteri fecal coliform dalam tanah.

\section{LANDASAN TEORI}

\section{Curah hujan}

Curah hujan berpengaruh pada kecepatan gerakan air tanah, hal ini dapat berpengaruh pada kecepatan pencemaran air dari resapan limbah terhadap sumber air bersih. Pada kondisi tempat yang sama, daerah dengan curah hujan tinggi, jarak sumber air bersih terhadap septic tank harus lebih jauh dibandingkan pada daerah dengan curah hujan rendah, karena resiko pencemarannya lebih tinggi (Kusnoputranto, 1986: 57).

\section{Distribusi Pori}

Menurut Tan (2000: 242) jumlah ruang pori ditentukan oleh susunan partikel dalam tanah. Pembagian pori tanah didasarkan pada besarnya tegangan air (?), dinyatakan dalam satuan Hekto Pascal $(\mathrm{hPa})$ dan ukuran diameter pori (D), dinyatakan dalam satuan mikron meter $(\mu \mathrm{m})$. Terdapat 3 jenis pori penyusun tanah, yaitu pori makro (?< $60 \mathrm{hPa}, \mathrm{D}<10 \mu \mathrm{m}$ ), pori meso (?= 60-15.000 hPa, $\mathrm{D}=10-1000 \mu \mathrm{m})$, dan pori mikro (?> $15.000 \mathrm{hPa}, \mathrm{D}>1000$ $\mu \mathrm{m})$. Sebaran dari ketiga jenis pori inilah yang disebut dengan distribusi pori. Perbedaan proporsi jumlah pori makro, meso, dan mikro dalam tanah akan membedakan jumlah total pori pada berbagai tekstur tanah. Tanah bertekstur kasar (pasir) memiliki total ruang pori antara $35-50 \%$, 
sedangkan tanah dengan tekstur halus (lempung dan debu) memiliki total ruang pori sebesar $40-60 \%$.

\section{Konduktivitas Hidraulik Tanah}

Konduktivitas hidraulik tanah merupakan kecepatan air dalam menempuh jarak tertentu matrik tanah. Menurut Foth (1998: 69-70), Konduktivitas hidraulik menggambarkan kemudahan pori tanah untuk meloloskan air. Hal ini sangat berpengaruh terhadap potensi pencemaran tanah oleh sumber pencemar, seperti halnya air resapan septic tank. Tanah dengan konduktivitas hidraulik tinggi dan memiliki ruang pori yang besar akan berpotensi mengalami pence-maran lebih tinggi (Anonim, 2006). Menurut Ellsworth et al., 1996; dalam Susilonegoro (2005), dengan mengetahui fungsi distribusi pori dan konduktivitas hidraulik dapat dibuat model gerakan air tanah.

Tabel 1. Kelas-kelas konduktivitas hidraulik

\begin{tabular}{ccc}
\hline \multirow{2}{*}{ Kelas } & \multicolumn{2}{c}{ Konduktivitas jenis } \\
\cline { 2 - 3 } & $\mu \mathrm{m} /$ menit & $\mathrm{cm} /$ hari \\
\hline Sangat tinggi & 100 & 864 \\
Tinggi & $10-100$ & $86,4-864$ \\
Sedang & $1=10$ & $8,64=86,4$ \\
Agak rendah & $0,1-1$ & $0,864-8,64$ \\
Rendah & $0,01=0,1$ & $0,0864=0,864$ \\
Sangat rendah & $<0,01$ & $<0,0864$ \\
\hline
\end{tabular}

Sumber: modifikasi dari Foth (1998: 70)

\section{Sumur Gali}

Sumur gali harus dilindungi dari bahaya pencemaran, agar memenuhi syarat kesehatan untuk dikonsumsi. Ada beberapa syarat yang harus dipenuhi dalam pembuatan sumur, yaitu: 


\section{a. Syarat lokalisasi}

Untuk menghindari pengotoran harus diperhatikan jarak sumur dengan berbagai sumber pencemar. Jarak ini tergantung pada keadaan tanah dan kemiringan tanah.

\section{b. Syarat konstruksi}

Dinding sumur bagian dalam dibuat tidak tembus air sedalam $3 \mathrm{~m}$ dari permukaan tanah (menghindari perembesan), sedangkan bagian luar dibuat setinggi minimal $70 \mathrm{~cm}$, lantai sumur dibuat agak miring selebar $1 \frac{1}{2}$ dan ditinggikan $20 \mathrm{~cm}$ di atas permukaan tanah. Panjang saluran pembuangan air dibuat minimal $10 \mathrm{~m}$ dari sekitar sumur.

Kapasitas penampungan air pada sumur gali dipengaruhi oleh besarnya diameter sumur tersebut. Faktor musim juga turut berpengaruh. Pada musim kemarau ketinggian permukaan air sumur akan menurun, oleh karena itu kedalaman sumur dibuat mencapai lapisan tanah yang mengandung air cukup banyak walaupun pada musim kemarau. Berdasarkan tingkat kedalaman air tanahnya, sumur dapat dibedakan menjadi 2 jenis, yaitu: Sumur dangkal $( \pm 30-100 \mathrm{~m})$ dan sumur dalam $( \pm 15-$
$30 \mathrm{~m}$ ). Air sumur dangkal ini belum begitu sehat, karena kontaminasi kotoran dari permukaan tanah masih ada (Notoatmodjo, 2003: 154 -155).

\section{Bakteri Fecal Coliform}

Fecal Coliform adalah salah satu jenis bakteri total coliform yang merupakan flora normal pada tinja dan saluran pencernaan manusia dan hewan. Merupakan bakteri batang lurus dengan ukuran 1,1-1,5 $\mu \mathrm{m} \mathrm{x}$ 2,0-6,0 $\mu \mathrm{m}$ (Pelczar, 2006: 949). Keberadaan bakteri ini pada sumber air mengindikasikan adanya kontaminasi fekal. Menurut PERMENKES 416/Menkes/Per/IX/1990 tentang Persyaratan Air Bersih, air yang berasal dari perpipaan maksimal mengandung bakteri coliform sebesar $10 \mathrm{MPN} / 100 \mathrm{ml}$ sampel air, sedangkan yang non perpipaan sebesar 50 MPN/ $100 \mathrm{ml}$.

\section{Pola Pencemaran Bakterial Ter- hadap Tanah. \\ Jarak yang ditempuh oleh bakteri maupun zat kimia (horizon- tal maupun vertikal) tergantung beberapa faktor, yang terpenting adalah porositas tanah (Kusno- putranto, 1986: 55).}




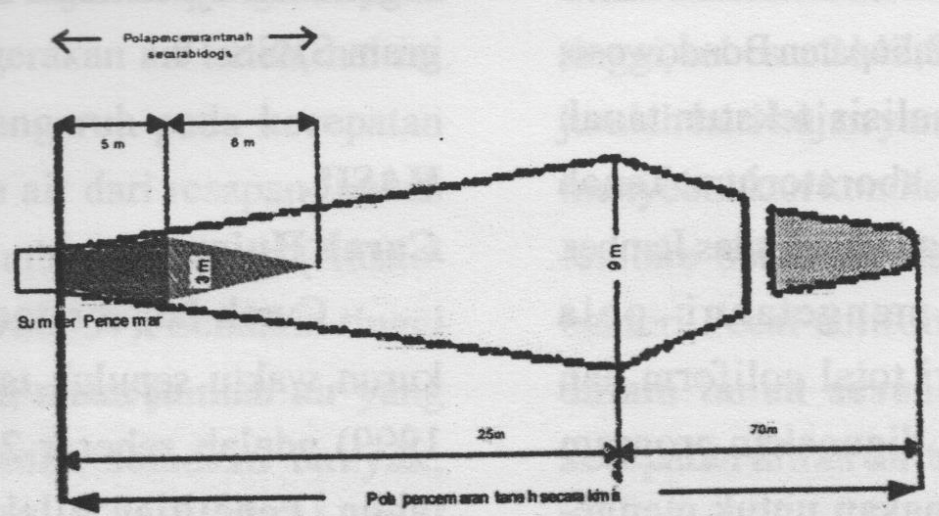

Sumber: Kusnoputranto (1986: 56)

Gambar 1..Pola Pencemaran Tanah oleh Bakteri dan Zat Kimia serta Maksimum Migrasi."

Bakteri akan berpindah secara horizontal dan vertikal bersamaan dengan air, atau air hujan yang meresap. Perpindahan horizontal melalui tanah $<90 \mathrm{~cm}$ dan ke bawah $<3 \mathrm{~m}$ pada lubang yang terbuka terhadap air hujan. Pada tanah berpori $<60 \mathrm{~cm}$ (Soeparman, 2001: 48).

Pola tersebut menggambarkan penyebaran tinja manusia sebagai sumber kontaminasi yang berasal dari lubang jamban serta menembus air tanah. Area dari kontaminasi melebar sampai $\pm 2 \mathrm{~m}$ pada jarak $5 \mathrm{~m}$ dari lubang serta menyempit hingga jarak $\pm 11 \mathrm{~m}$. Kontaminasi bersifat searah dengan arah aliran air tanah dan bukan sebaliknya. Pada jarak $25 \mathrm{~m}$ dari lubang jamban, area kontaminasi melebar sampai \pm 9 m untuk kemudian menyempit hingga jarak $\pm 11,5 \mathrm{~m}$.

\section{METODE PENELITIAN}

Penelitian dilakukan di Rumah Sakit Paru Jember. Sampel air diambil dari sumur gali dapur, sedangkan sampel tanah diambil dari tanah resapan septic tank yang terdiri dari 3 titik dengan 5 kedalaman, yaitu jarak 4,5 m dari sumur gali (kedalaman 40-60 cm dan 140-160 $\mathrm{cm}$ ), jarak $9 \mathrm{~m}$ (kedalaman 0-25 cm, $40-60 \mathrm{~cm}, 90-110 \mathrm{~cm}, 140-160 \mathrm{~cm}$, dan $\mathrm{cm}$ ), jarak 13,5 m (kedalaman 0$25 \mathrm{~cm}, 40-60 \mathrm{~cm}, 140-160 \mathrm{~cm}$, dan $190-210 \mathrm{~cm}$ ). Analisis mikrobiologis 
air dan tanah dilakukan di Laboratorium Kesehatan Kabupaten Bondowoso, sedang-kan analisis tekstur tanah dilakukan di Laboratorium Tanah Fakultas Pertanian Universitas Jember.

Untuk mengetahui pola sebaran bakteri total coliform dan fecal coliform, digunakan program Surfer 8, sedangkan untuk mengetahui distribusi pori dan konduktivitas hidraulik tanah digunakan program RETC 6.1. Sedangkan untuk mengetahui kuat hubungan antara jarak resapan septic tank dengan pergerakan fecal coliform digunakan uji kendall dengan program SPSS 10.

\section{HASIL}

\section{Curah Hujan}

Curah hujan rata-rata selama kurun waktu sepuluh tahun (19901999) adalah sebesar $2142,8 \mathrm{~mm} /$ tahun. Penelitian dilakukan pada bulan Agustus, September dan November. Besarnya curah hujan masingmasing bulan adalah $53,33 \mathrm{~mm} /$ bulan, $47,5 \mathrm{~mm} /$ bulan dan $246,8 \mathrm{~mm} /$ bulan, dengan rata-rata jumlah hari hujan 3,5 hari, 4,2 hari dan 13,6 hari.

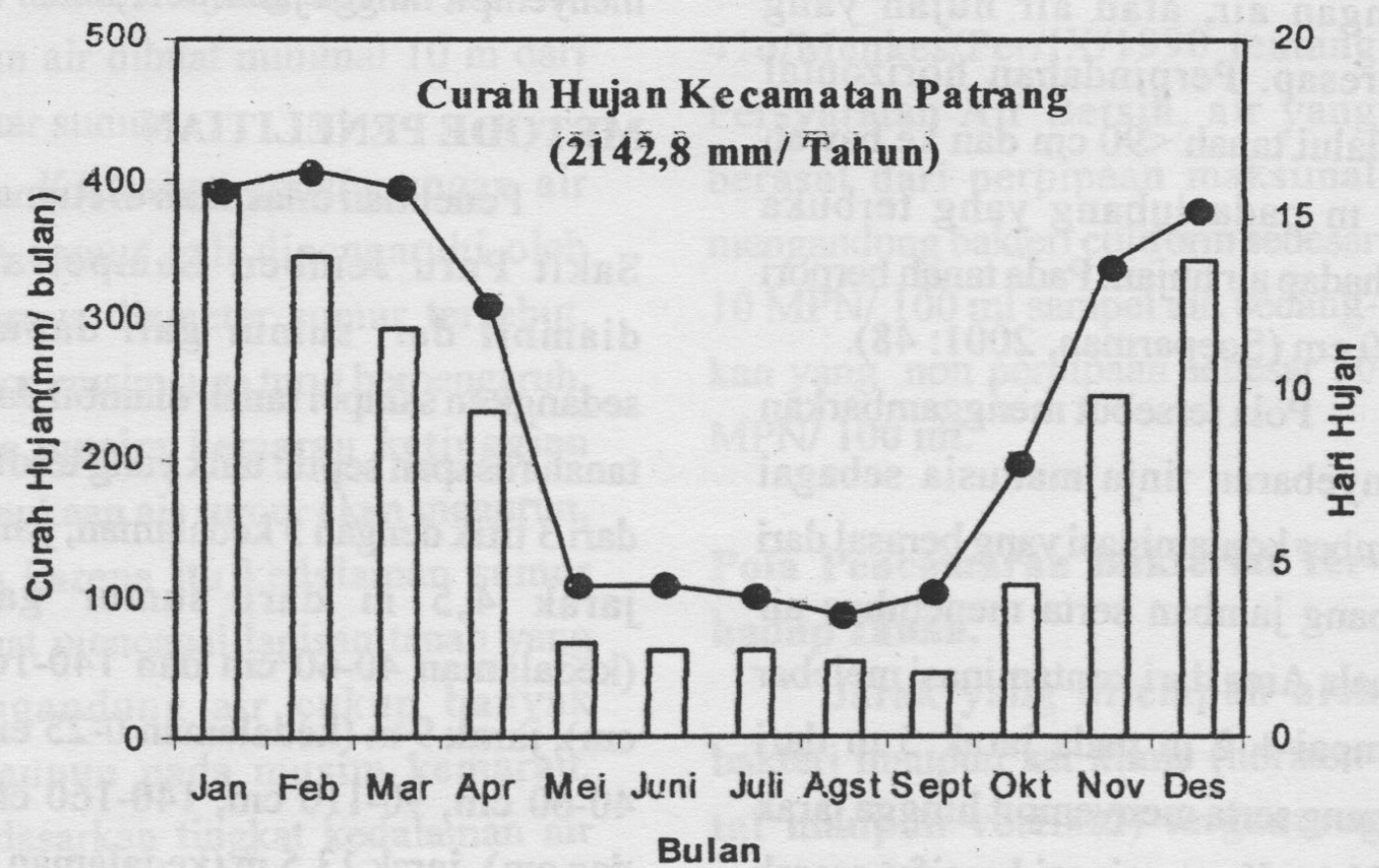

Gambar 2. Curah hujan Kecamatan Patrang Tahun 1990-1999 
Curah hujan berpengaruh pada kecepatan gerakan air tanah, hal ini dapat berpengaruh pada kecepatan pencemaran air dari resapan limbah terhadap sumber air bersih (Kusnoputranto, 1986: 57). Semakin tinggi curah hujan, maka jumlah air yang diterima tanah semakin banyak, keadaan tanah akan semakin lembab sehingga air akan terserap masuk ke lapisan tanah yang lebih dalam. Banyaknya jumlah air hujan yang masuk ke dalam tanah dipengaruhi oleh jenis tanah. Gerakan air di dalam tanah ini akan membawa bakteri dalam tanah untuk menyebar sesuai dengan arah kecepatan aliran air tanah (Anonim 2007). Curah hujan dikecamatan Patrang yang relatif tinggi, sebesar 2142,8 mm/tahun dan jumlah hari hujan yang relatif banyak menyebabkan kondisi tanah menjadi lembab sehingga dapat membawa bakteri Fecal coliform menyebar ke dalam tanah sesuai dengan arah kecepatan aliran air tanah.

\section{Tekstur Tanah}

Jarak resapan antara sumur gali dan septic tank sejauh $15 \mathrm{~m}$, sehingga tanah dapat diasumsikan homogen. Oleh karenanya tekstur tanah hanya diperiksa pada 1 titik jarak saja (jarak $9 \mathrm{~m}$ dari sumur gali). Sampel tanah diambil dari 5 titik kedalaman yang berbeda.

Tabel 2. Kelas Tekstur Tanah Pada Berbagai Kedalaman Tanah

\begin{tabular}{ccccc}
\hline $\begin{array}{c}\text { Kedalaman } \\
(\mathrm{Cm})\end{array}$ & \% Pasir & \% Debu & $\begin{array}{c}\% \\
\text { (Lempung) }\end{array}$ & Kelas Tekstur \\
\hline $0-25$ & 40 & 42,2 & 17,8 & loam (lempung) \\
$40-60$ & 31,2 & 64,5 & 4,3 & silt loam (lempung berdebu) \\
$90-110$ & 29 & 45 & 26 & loam (lempung) \\
$140-160$ & 26 & 48,7 & 25,3 & loam (lempung) \\
$190-210$ & 4 & 38,4 & 20,6 & loam (lempung) \\
\hline
\end{tabular}

Sumber : Data Primer Terolah, 2007 


\section{Distribusi Pori Tanah}

Besarnya distribusi pori pada masing-masing sampel tanah, yaitu pada sampel tanah kedalaman 0-25 cm, 40-60 cm, 140-160 cm, dan 190-210 $\mathrm{cm}$ disajikan pada gambar 3. Sampel tanah kedalaman 90-110 cm tidak disajikan karena memiliki karakteristik yang sama dengan sampel tanah kedalaman 140-160 cm, sehingga dapat diasumsikan relatif sama.

Pada keadaan jenuh (ruang pori total seluruhnya terisi air), nilai? (water content) terbesar dimiliki oleh tanah Silt loam (lempung berdebu) kedalaman $40-60 \mathrm{~cm}$ sebesar 0,449 $\mathrm{cm} . \mathrm{cm}-3$. Artinya pada tegangan jenuh tanah Silt loam (lempung berdebu) mempunyai kemampuan paling baik dalam menahan air dibandingkan keempat sampel tanah lainnya yang memiliki tekstur Loam (lempung) karena memiliki ruang total pori terbesar. Namun kemampuan tanah menahan air ini, erat kaitannya dengan sebaran pori tanah. Perlu diperhatikan juga jumlah sebaran pori dalam tanah, karena hal ini akan berpengaruh pada kapasitas penahanan air.

Perbedaan distribusi pori pada kelima sampel tanah, dipengaruhi oleh perbedaan kelas tekstur tanah. Dari 5 sampel yang diteliti, terdapat 2 jenis kelas tekstur tanah yaitu: loam dan silt loam. Tanah silt loam mempunyai total ruang pori yang lebih besar (45\%) dibandingkan keempat sampel tanah lain yang bertekstur loam (sekitar 40$43 \%$ ). Perbandingan distribusi pori (pori makro, meso dan mikro) pada kelima sampel didominasi oleh pori meso.

Tabel 3. Persentase Distribusi Pori Sampel Tanah Pada Berbagai Kedalaman

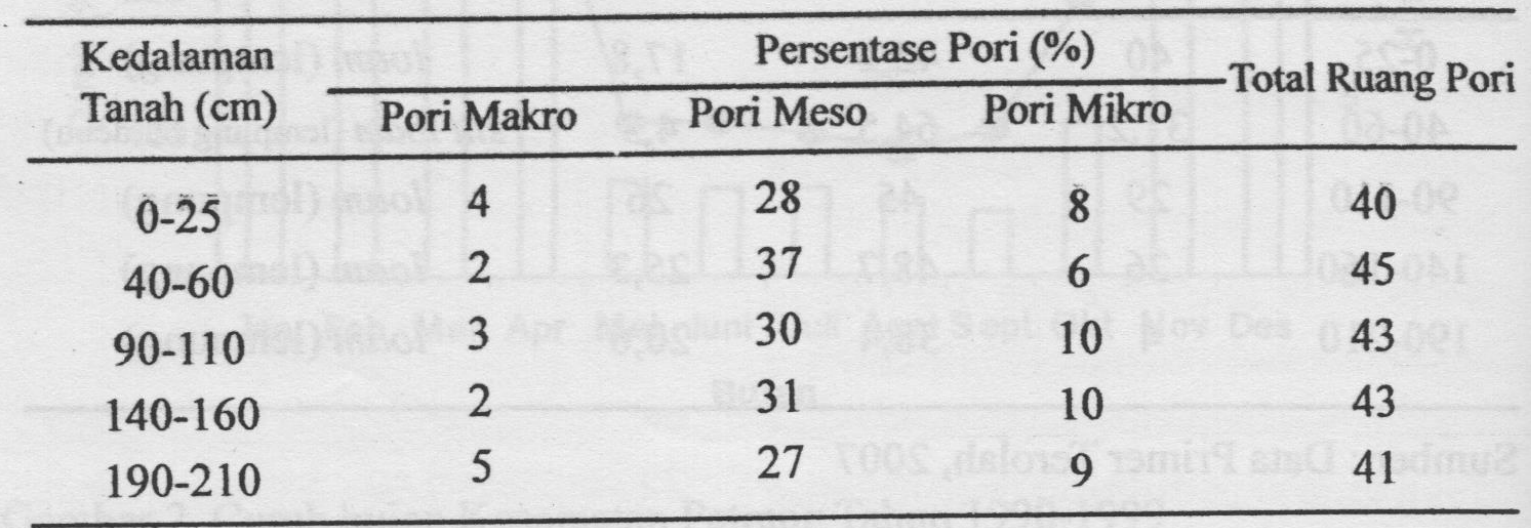

Sumber : Data Primer Terolah, 2008 
Menurut Giestanto (2006), jenis dan kadar liat mempengaruhi porositas, jenis dan konfigurasi pori dalam tanah, semakin tinggi kadar liat berarti pori mikro semakin dominan, maka kemampuan tanah untuk menahan air semakin tinggi. Pada tanah Loam kedalaman 90-110 cm

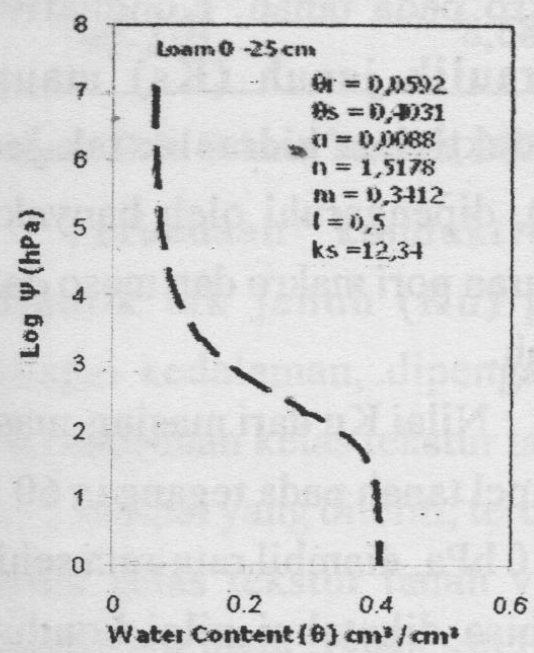

(a)

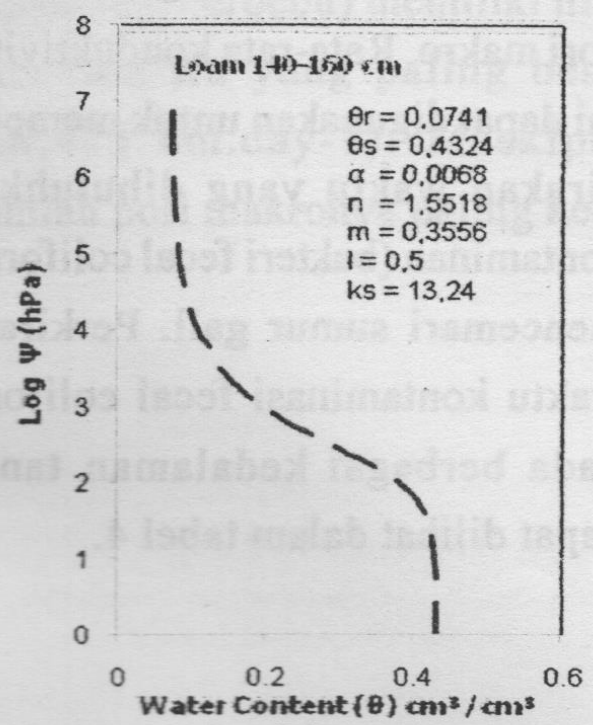

(c) kadar liatnya sebesar $25,6 \%$ sedangkan pada kedalaman 140-160 cm sebesar $25,3 \%$, merupakan sampel tanah yang memiliki fraksi liat terbanyak. Oleh karena itu kedua jenis sampel tanah tersebut memiliki kapasitas penahan air yang relatif lebih besar dibandingkan sampel lainnya.

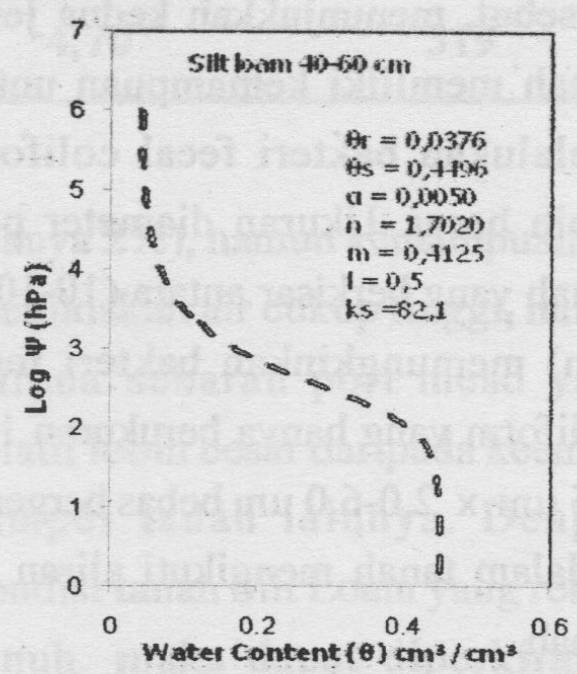

(b)

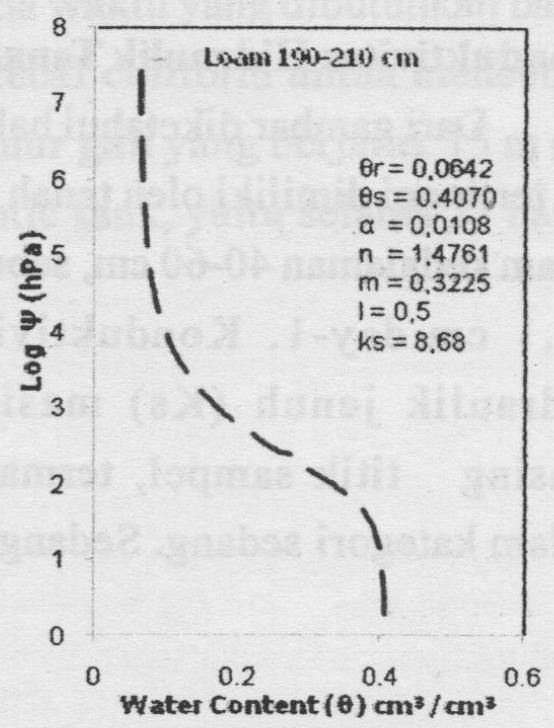

(d) 
(a) Distribusi pori tanah kedalaman 0-25 cm; (b) Distribusi pori tanah kedalaman 40-60 $\mathrm{cm}$; (c) Distribusi pori tanah kedalaman 140-160 cm; (d) Distribusi pori tanah kedalaman 190-210 cm;

Gambar 3. Model Distribusi Pori Tanah pada Berbagai Kedalaman

Dominasi distribusi pori meso dibandingkan kedua jenis pori yang lain pada kedua tekstur tanah tersebut, menunjukkan kedua jenis tanah memiliki kemampuan untuk melalukan bakteri fecal coliform lebih besar. Ukuran diameter pori tanah yang berkisar antara $(10-1000$ $\mu \mathrm{m})$ memungkinkan bakteri fecal coliform yang hanya berukuran 1,1$1,5 \mu \mathrm{m} \times 2,0-6,0 \mu \mathrm{m}$ bebas bergerak didalam tanah mengikuti aliran air tanah.

\section{Konduktivitas Hidraulik Tanah}

Dari gambar diketahui bahwa Ks tertinggi dimiliki oleh tanah Silt Loam kedalaman $40-60 \mathrm{~cm}$, sebesar $82,1 \mathrm{~cm}$.day-1. Konduktivitas hidraulik jenuh (Ks) masingmasing titik sampel, termasuk dalam kategori sedang. Sedangkan untuk konduktivitas hidraulik tak jenuh $(\mathrm{Ku})$ dapat dihitung rataratanya berdasarkan sebaran pori makro pada tanah. Konduktivitas hidraulik jenuh (Ks) maupun konduktivitas hidraulik tak jenuh (ku), dipengaruhi oleh banyaknya sebaran pori makro dan meso dalam tanah.

Nilai Ku dari masing-masing sampel tanah pada tegangan $60 \mathrm{hPa}$ dan $0 \mathrm{hPa}$, diambil rata-rata sehingga bisa diketahui nilai konduktivitas ratarata tanah dengan sebaran pori makro. Rata-rata konduktivitas ini dapat digunakan untuk memperkirakan waktu yang dibutuhkan kontaminan (bakteri fecal coliform) mencemari sumur gali. Perkiraan waktu kontaminasi fecal coliform pada berbagai kedalaman tanah dapat dilihat dalam tabel 4 . 
Pola Pencemaran Bakteri...... Asri D. Vtami, dkk.

Tabel 4.Perkiraan Waktu Kontaminasi Fecal Coliform Pada Berbagai Kedalaman Tanah Berdasarkan Kecepatan Konduktivitas Hidraulik

\begin{tabular}{cccc}
\hline Kedalaman $(\mathrm{cm})$ & Ks (cm/days) & $\begin{array}{c}\text { Rata-Rata Ku } \\
(\mathrm{cm} / \text { days })\end{array}$ & $\begin{array}{c}\text { Perkiraan Lama } \\
\text { Kontaminasi (Hari) }\end{array}$ \\
\hline $0-25$ & 12,34 & 6,93 & 216 \\
$40-60$ & 82,1 & 56,47 & 27 \\
$90-110$ & 12,84 & 7,42 & 202 \\
$140-160$ & 13,24 & 7,9 & 190 \\
$190-210$ & 8,68 & 4,70 & 319 \\
\hline
\end{tabular}

Sumber : Data Primer Terolah, 2007

Perbedaan konduktivitas hidraulik tak jenuh $(\mathrm{Ku})$ pada berbagai kedalaman, dipengaruhi oleh perbedaan kelas tekstur tanah. Dari 5 sampel yang diteliti, terdapat 2 jenis kelas tekstur tanah yaitu: loam dan silt loam. Tanah Silt Loam (Lempung berdebu) memiliki nilai rata-rata $\mathrm{Ku}$ yang paling besar (56,475 cm.day-1). Meskipun jumlah pori makronya paling kecil (hanya $2 \%$ ), namun kemampuannya meloloskan air cukup tinggi, hal ini karena sebaran pori meso yang relatif lebih besar daripada keempat sampel tanah lainnya. Dengan kondisi tanah Silt Loam yang relatif jenuh, maka dapat diperkirakan lama waktu yang dibutuhkan bakteri fecal coliform untuk mencemari sumur gali yang berjarak $15 \mathrm{~m}$ dari septic tank, yaitu selama 27 hari. 


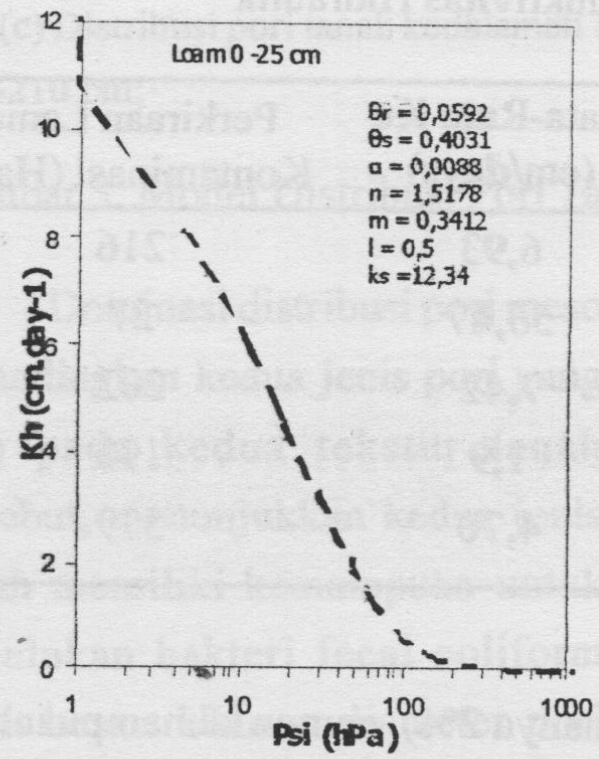

(a)

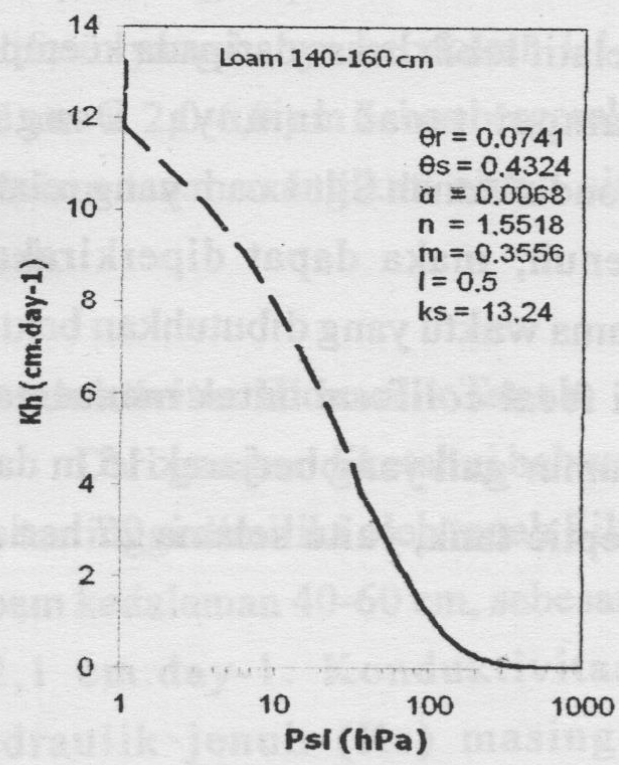

(c)

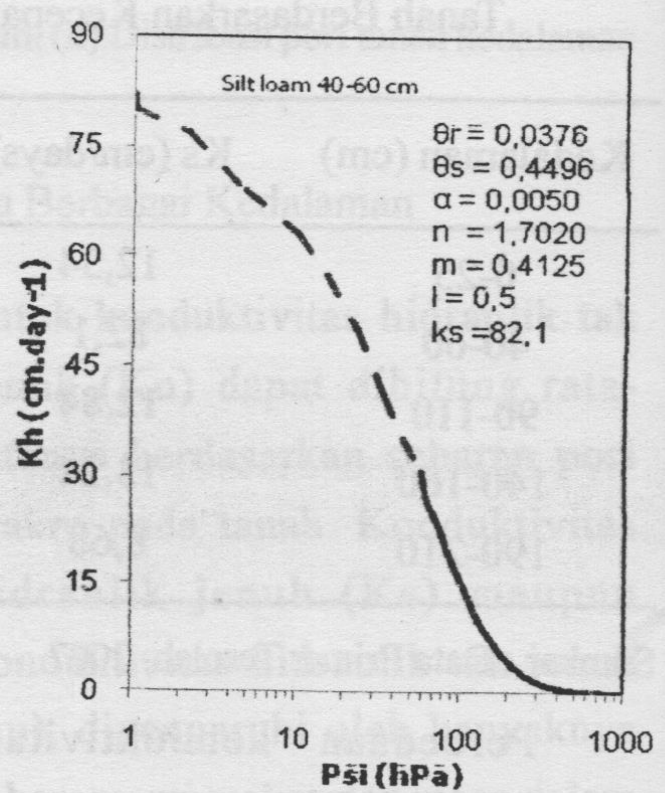

(b)

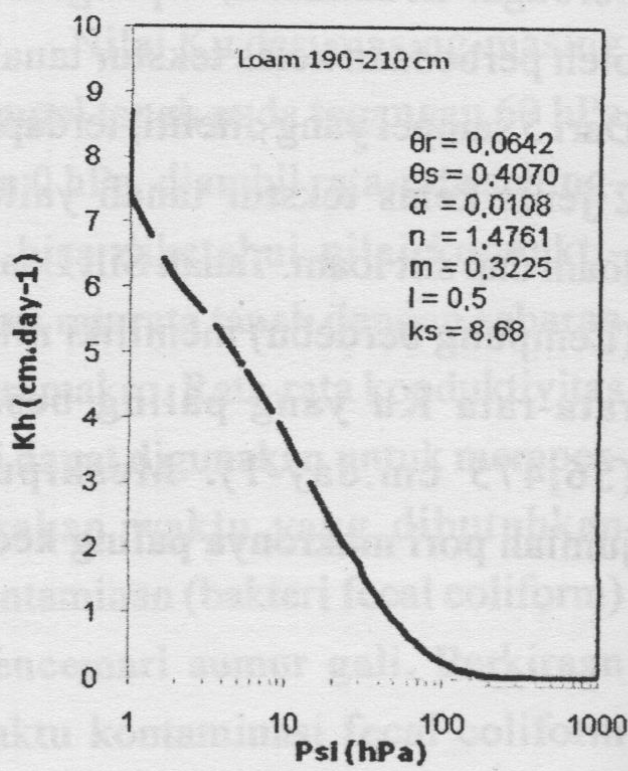

(d)

(a) Konduktivitas hidraulik tanah kedalaman 0-25 cm; (b) Konduktivitas hidraulik tanah kedalaman 40-60 cm; (c) Konduktivitas hidraulik tanah kedalaman 140-160 cm; (d) Konduktivitas hidraulik tanah kedalaman 190-210 cm;

Gambar 4.3 Konduktivitas Hidraulik Tanah Pada Berbagai Kedalaman 
Distribusi pori makro pada tanah silt loam lebih sedikit (2\%) dibandingkan pada tanah loam (2-5\%), oleh karena itu tanah tekstur loam lebih mudah dilalui air dibanding-kan tekstur silt loam. Tanah silt loam merupakan dengan tekstur halus, yang mempunyai ruang pori total lebih banyak dan proporsi pori makro dan mikronya relatif lebih sedikit, namun sebaran pori mesonya lebih besar akibatnya tanah mempunyai konduktivitas hidraulik yang tinggi, sehingga gerakan air dalam tanah menjadi lebih cepat (Foth, 1998).

Perret et al, 1999 dalam Agustin (2007), berpendapat bahwa ukuran dan hubungan pori tanah mempunyai peranan yang penting dalam karakteristik aliran air dan pengangkutan larutan dalam tanah. Pori yang besar dan kontinyu mampu mengadakan pengangkutan air. Semakin besar radius hidraulik, semakin besar pula kapasitas pengangkutan.

Kualitas Mikrobiologi Air dan Tanah Air Sumur Gali

Jenis sumur yang dipakai di Rumah Sakit Paru adalah sumur gali yang dilengkapi pompa, memiliki kedalaman sekitar $10 \mathrm{~m}$. Sumur dengan kedalaman tersebut masih rentan terhadap kontaminasi. Hasil pemeriksaan terhadap kandungan bakteri coliform sumur gali menunjukkan angka $>2400 \mathrm{JPT} / 100$ ml sampel air, sedangkan kandungan bakteri fecal coliform sumur gali menunjukkan angka $>2400 \mathrm{JPT} / 100$ ml sampel air. Dapat diasumsikan bahwa berdasarkan parameter biologi, air tersebut tidak memenuhi syarat kesehatan karena telah melebihi ambang batas yang diperkenankan sebesar $10 \mathrm{JPT} / 100 \mathrm{ml}$ untuk air dari perpipaan dan $50 \mathrm{JPT} /$ $100 \mathrm{ml}$ untuk air non perpipaan, oleh karenanya perlu pengolahan lagi jika akan dikonsumsi.

\section{Tanah Resapan}

Total coliform diperiksa pada 10 titik, yaitu jarak 4,5 m (kedalaman 40-60 cm dan 140-160 cm), jarak 9 m (kedalaman 0-25 cm, 40-60 cm, 90$110 \mathrm{~cm}, 140-160 \mathrm{~cm}$, dan $190-210$ $\mathrm{cm}$ ), dan 13,5 m (kedalaman 40-60 $\mathrm{cm}, 140-160 \mathrm{~cm}$, dan $190-210 \mathrm{~cm}$ ). Pusat sebaran total coliform berada pada jarak 9 dari sumur, sebanyak 2400 MPN pada kedalaman 0-1m. 
Fecal coliform diperiksa dari 5 titik, yaitu jarak 4,5 (kedalaman 40-60 $\mathrm{cm}$ ), dan jarak 13,5 (kedalaman 0-25 $\mathrm{cm}, 40-60 \mathrm{~cm}, 149-160 \mathrm{~cm}$, dan $190-$ $210 \mathrm{~cm}$ ). Pusat fecal coliform berada pada jarak 13,5 m dari sumur, atau dekat dengan septic tank sebagai sumber kontaminasi, sebaran fecal coliform berkisar antara 0-1600 MPN. Dari deskripsi sebaran total coliform tersebut terlihat bahwa jumlah MPN total coliform tertinggi terdapat pada bagian atas lapisan tanah (kedalaman
0-1,5 m). Semakin dalam lapisan tanah jumlah bakteri total coliform semakin sedikit, hal ini dikarenakan bakteri ini hanya mampu hidup di tanah dengan kedalaman maksimal 3 m. Keberadaan bakteri fekal coliform dapat diartikan bahwa tanah telah terkontaminasi materi fekal. Tanah resapan didekat sumur gali telah terkontaminasi materi fekal, bahkan air sumur gali telah positif mengandung fekal coliform, yang berarti air sumur telah terkontaminasi materi fekal.

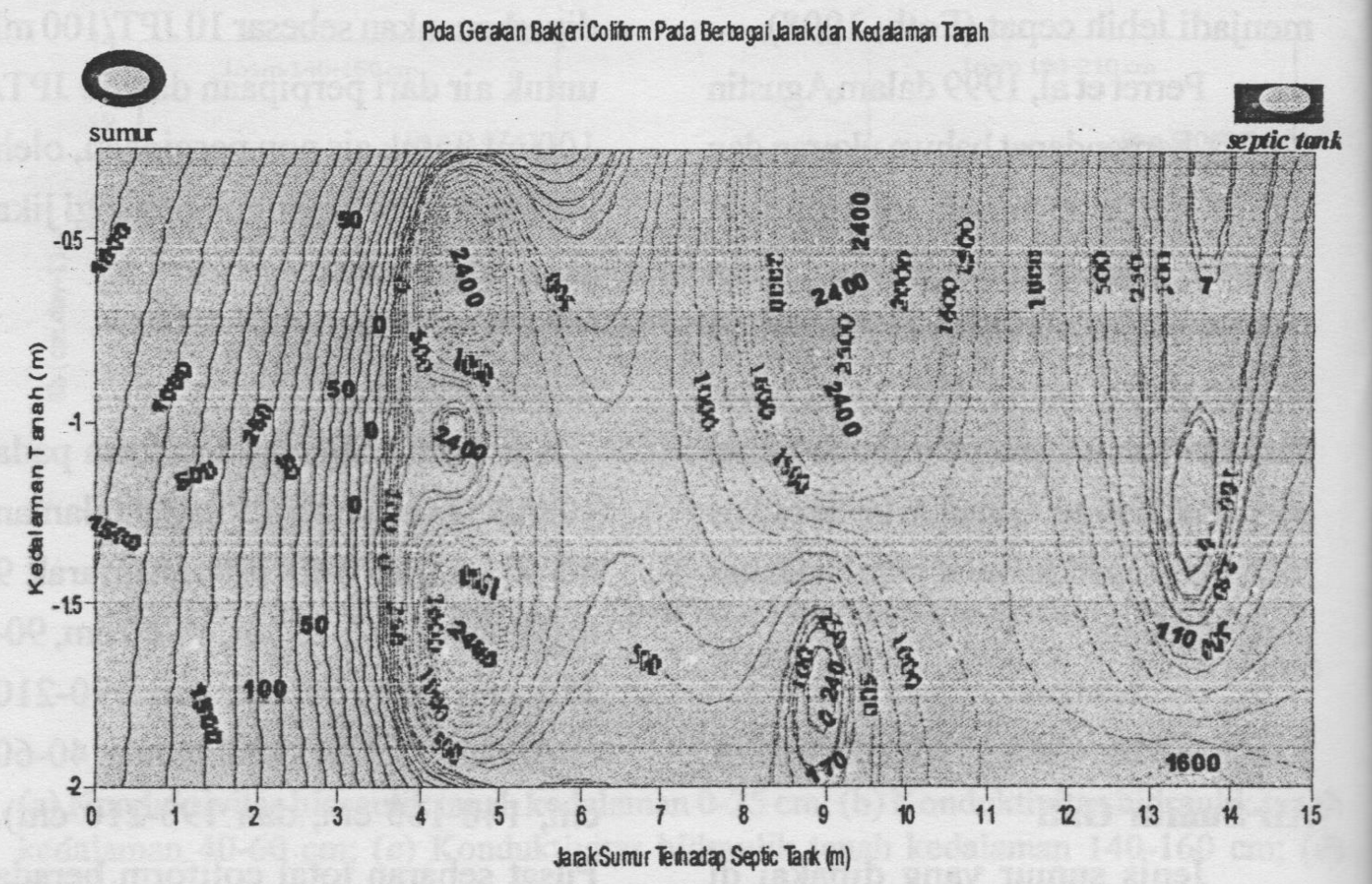

Sumber: Data primer terolah, 2007

Gambar 5. Pola sebaran total coliform pada berbagai jarak dan kedalaman tanah 


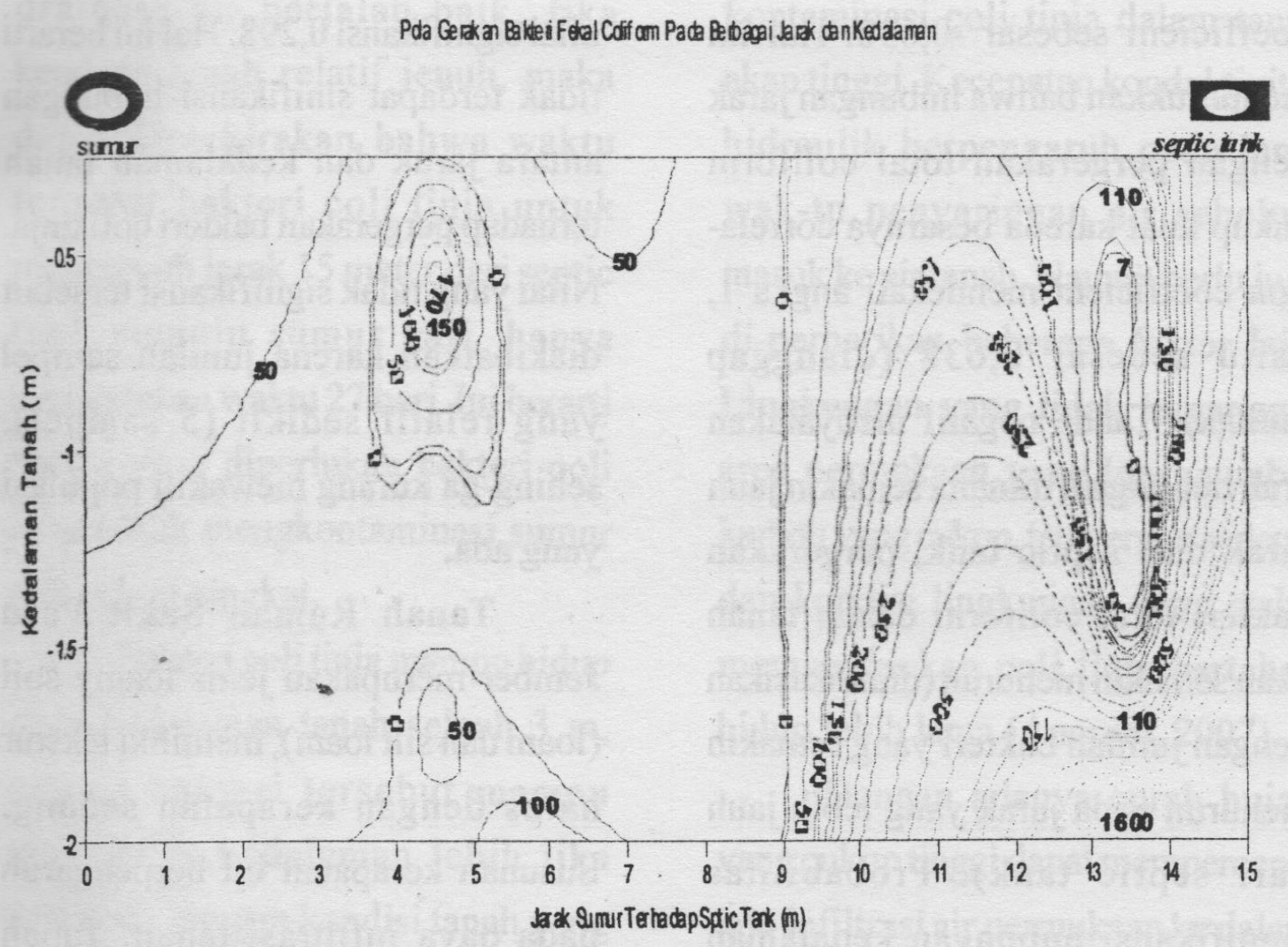

Sumber: Data primer terolah, 2007

Gambar 6. Pola sebaran fecal coliform pada berbagai jarak dan kedalaman tanah

Dalam hasil penelitiannya, Coyne, et al (1997) mengatakan bahwa jumlah bakteri fecal coliform terbanyak adalah pada lapisan tanah yang dekat dengan permukaan, gerakan bakteri pada lapisan ini dapat menuju ke arah dan kedalaman manapun tergantung pada kontinyuitas pori tanah.
Pola Pencemaran Bakteri Fecal Coliform Pada Tanah Resapan Septic Tank

Probabilitas signifikansi dari uji Kendall yang menyatakan hubungan jarak resapan dengan total coliform sebesar $0,027<0,05$, yang berarti terdapat signifikansi hubungan keduanya. Besarnya correlation 
coefficient sebesar $-0,638$. Hal ini menunjukkan bahwa hubungan jarak dengan pergerakan total coliform cukup kuat karena besarnya correlation coefficient mendekati angka 1 , yaitu sebesar 0,638 (dianggap mutlak). Tanda negatif menyatakan arah hubungan, dimana semakin jauh jarak dari septic tank, pergerakan bakteri total coliform dalam tanah akan sémakin menurun (diindikasikan dengan jumlah bakteri yang semakin menurun pada jarak yang lebih jauh dari septic tank). Probabilitas signifikansi hubungan kedalaman tanah dengan total coliform sebesar $0,275>0,05$, yang berarti tidak terdapat signifikansi hubungan keduanya. Dari hasil uji tersebut dapat diketahui bahwa terdapat hubungan antara jarak dan pergerakan bakteri total coliform, sedangkan variabel kedalaman tidak berhubungan.

Sedangkan untuk probabilitas signifikansi hubungan jarak dengan pergerakan coli tinja sebesar $0,468>$ 0,05 , yang berarti tidak terdapat signifikansi. Begitu pula dengan hubungan kedalaman tanah dengan pergerakan coli tinja, yang memiliki nilai signifikansi 0,298 . Hal ini berarti tidak terdapat sinifikansi hubungan antara jarak dan kedalaman tanah terhadap pergerakan bakteri coli tinja. Nilai yang tidak signifikansi tersebut diakibatkan karena jumlah sampel yang relatif sedikit (5 sampel), sehing-ga kurang mewakili populasi yang ada.

Tanah Rumah Sakit Paru Jember merupakan jenis loamy soil (loam dan silt loam), memiliki tekstur halus dengan kerapatan sedang. Susunan kerapatan ini berpengaruh pada daya infiltrasi tanah. Tanah bertekstur halus mempunyai daya infiltrasi rendah, sehingga aliran air dipermukaan akan semakin tinggi dan kemampuan tanah menyerap air berkurang. Hal ini menyebabkan pola pencemaran akan lebih cenderung kearah horizontal, bukan vertikal. Dengan kata lain, penyebaran coliform dan coli tinja mengikuti arah horizontal septic tank dengan sumur gali bukan arah vertikal (kedalaman tanah).

Menurut Soegianto (2005:63), tekstur loamy soil (loam maupun silt loam ) mempunyai porositas yang cukup sehingga sirkulasi udara dan 
drainase air berjalan baik. Jika keadaan tanah relatif jenuh, maka dapat diperkirakan bahwa waktu tercepat bakteri coli tinja untuk menempuh jarak 15 meter dari septic tank menuju sumur gali, hanya memerlukan waktu 27 hari. Ini berarti waktu yang diperlukan bakteri coli tinja untuk mengkontaminasi sumur gali relatif singkat.

Bakteri coli tinja mampu hidup pada kedalaman tanah sejauh $3 \mathrm{~m}$, namun bakteri tersebut mampu menembus kedalaman lebih jika didukung dengan kondisi tanah yang optimal untuk pertumbuhannya. Coyne, et al (1997) mengatakan bahwa jumlah bakteri coli tinja terbanyak adalah pada lapisan tanah yang dekat dengan permukaan, gerakan bakteri pada lapisan ini dapat menuju ke arah dan kedalaman manapun tergantung pada kontinyuitas pori tanah. Tanah dengan aerasi yang baik lebih memungkinkan bakteri bertahan hidup ditanah dalam jangka waktu yang lebih lama. Jika kedalaman air tanah rendah, sebaran pori makro tinggi, dan kecepatan konduktivitas tanah tinggi, maka kontaminasi coli tinja dalam tanah akan tinggi. Kecepatan konduktivitas hidraulik berpengaruh pada lama wak-tu penyaringan air sebelum masuk ke air tanah. Namun perlu juga di-perhatikan beberapa faktor lain. Lingkungan yang tidak terganggu, area permukaan yang luas, sumber karbon yang cukup, temperatur sedang, dan kondisi lingkungan yang stabil memungkinkan coli tinja bertahan hidup lebih lama (Anonim, 2007).

Dengan adanya curah hujan yang cukup tinggi dapat mempercepat laju infiltrasi air permukaan ke dalam tanah. Faktor lain seperti jenis sumur dan kedalaman sumur juga berpengaruh terhadap jumlah bakteri coli tinja pada sumur gali. Pada musim kemarau ketinggian permukaan air sumur akan menurun. Penurunan jumlah air dalam sumur juga akan berpengaruh pada bakteri coli di dalamnya. Sumur gali yang tidak bertutup atau memiliki konstruksi yang kurang sempurna lebih rentan terhadap kontaminasi bakteri coli tinja.

Menurut Soeparman, dkk (2000: 73-74) dalam pembuatan resapan harus dibuat pada lapisan 
tanah yang berpori. Untuk mengurangi timbulnya bahaya pencemaran tanah, maka sumur resapan harus ditempatkan pada tanah yang lebih rendah, sekurang-kurangnya pada jarak $15 \mathrm{~m}$ dari sumber air minum dan sumur. Dari penelitian yang telah dilakukan, diketahui septic tank dapur Rumah Sakit Paru berjarak 15 m dari sumur gali dan ditempatkan pada tanah yang tebih rendah daripada sumur. Namun dalam sumur gali tersebut ternyata diketemukan bakteri coli tinja dalam jumlah yang cukup besar (?2400 MPN/ $100 \mathrm{ml}$ ) dibandingkan dengan jumlah yang ada dalam tanah resapan. Distribusi bakteri coli tinja paling banyak pada tanah resapan yang jaraknya dekat dengan septic tank.

Secara topografi, sumur gali terletak pada tanah yang lebih tinggi dibandingkan septic tank, sehingga untuk mencemari sumur gali bakteri coli tinja harus bergerak melawan arah aliran air. Hal itu memiliki kemung-kinan yang sangat kecil, sehingga dapat di asumsikan bahwa pence-maran fekal yang terjadi pada sumur gali bukan bersumber dari sep- tic tank dapur, melainkan berasal dari septic tank lain yang berada pada tanah yang lebih tinggi dari pada sumur gali. Kemampuan pergerakan bakteri tergantung pada karakteristik tanah seperti tekstur, konduktivitas hidraulik dan distribusi pori dan luas penye-barannya dalam air tanah tergantung pada intensitas dan lamanya curah hujan serta kedalaman air tanah (Coyne, et al , 1997).

\section{KESIMPULAN}

Tanah resapan Septic tank bertekstur loam dan silt loam yang yang didominasi oleh pori meso dengan kecepatan konduktivitas hidraulik sedang menyebabkan tanah mudah melalukan bakteri fecal coliform. Namun, daya infiltrasinya rendah sehingga aliran air di permukaan tanah tinggi (kemampuan menyerap air rendah), menyebabkan pola pencemaran akan lebih cenderung kearah horizontal. Pola kontaminasi fekal berpusat pada jarak $13,5 \mathrm{~m}$ dari sumur (dekat septic tank) telah menyebar dalam tanah resapan dan telah mencapai sumur gali (ke dalaman $10 \mathrm{~m}$ ) yang berjarak $15 \mathrm{~m}$ 
Pola Pencemaran Bakteri...... Asri D. Vtami, dkא.

dari septic tank, secara topografi letaknya lebih tinggi. Dari hal ini dipastikan bahwa sumber pencemaran fekal bukan berasal dari septic tank dapur, melainkan dari septic tank lain yang berada pada tanah yang lebih tinggi karena sumur gali .

\section{REKOMENDASI}

Kondisi tanah Rumah Sakit Paru Jember yang kurang baik, tidak menguntungkan jika digunakan

\section{DAFTAR PUSTAKA}

Agustin, Eni. 2007. Penentuan Konduktivitas Hidraulik Tanah Tidak Jenuh Dengan Tensiohigrometri dan Perbandingannya Terhadap Model Empiris Mualem. Tidak Dipublikasikan. Skripsi. Jember: Fakultas Pertanian.

Coyne, M.S., Howell, J.M., \& Phillips, R.E. 1997. How Do Bacteria Move Through Soil. [Serial On Line]. Journal of Agronomy, Vol.18 No.1. from: http://www.uky.edu/Ag/ Agronomy/Extension/ssnv/ ssvl181.htm. [22 November 2007]. sebagai tanah resapan septic tank. Oleh karena itu, hendaknya perlu dilaksanakan tindakan realisasi pembuatan instalasi pengolahan limbah yang memenuhi standar seperti pengoperasian kolam stabilisasi air limbah, kolam oksidasi air limbah, dan anaerobic filter treatment system, agar pembuangan limbah cair tidak lagi dibuang ke dalam septic tank.

Foth, Henry. 1988. Dasar-Dasar Ilmu Tanah. Yogyakarta: Gajahmada University Press

Giestanto, Arie D. 2006. Kajian Dinamika Air Tanah Pada Berbagai Tekstur dan Berat Volume Tanah. Tidak Dipublikäsikān. Skripsi. Jember: Fakultas Pertanian.

Kusnoputranto, Haryoto. 1986. Kesehatan Lingkungan. Jakarta: Fakultas Kesehatan Masyarakat Universitas Indonesia

Lembaga Penelitian Lingkungan Hidup. Tanpa Tahun. Data Curah Hujan Kecamatan Patrang Tahun 1977-1999. Jember 
Notoatmodjo, Soekidjo. 2003. Ilmu Kesehatan Masyarakat: Prinsip-Prinsip Dasar. Jakarta: CV. Rineka Cipta

Pelczar, Michael J. 2006.Dasar-dasar Mikrobiologi 2. Jakarta: Penerbit Universitas Indonesia.

Soegianto, Agus. 2005. Ilmu Lingkungan: Sarana Menuju Masyarakat Berkelanjutan. Surabaya: Airlangga University press.

Soeparman, Soeparmin. 2001. Pembuangan Tinja dan Limbah Cair. Jakarta: Penerbit EGC

Susilonegoro, Fainta. 2005. Pemanfaatan Gipsblock Untuk Pe- nentuan Tegangan Tidak Jenuh Air-Tanah. Tidak Dipublikasikan. Skripsi. Jember: Fakultas Pertanian.

Tan, Kim. H. 2000. Environmental Soil Science: Second Edition. New York: Marcel Dekker Inc.

Wisaksono, S. 2001. Karakteristik Limbah Rumah Sakit dan Pengaruhnya Terhadap Kesehatan dan Lingkungan. [Serial On Line]. http://kalbefarma.com.files/cdk/files/17 karakteristik limbah rumah sakit dan pengaruhnya terhadap kesehatan dan lingkungan.htm. [5 Maret 2007] 